\title{
A DIFFERENT ATTEMPT TO READ THE DISCLOSURE MECHANISM: REVIEW OF DISCLOSURE ASSESMENT COMMISSION IN TERMS OF PUBLIC LOSS
}

\author{
Selin OVALIOĞLU1
}

\begin{abstract}
The purpose of this study is to determine the rights and obligations of the disclosure assessment commissions and to dispute their responsibility to compensate if the disclosure mechanism is operated in contradiction with the law. In this context, firstly, the conditions sought for the emergence of public loss in terms of the imposition, accrual, and collection of public revenues and the financial responsibility of public boards, committees, and commissions are examined and then, the results arising from the determination of public loss briefly discussed. In the second section, general information about the disclosure assessment commissions is given. In the third section, it is aimed to determine the rights and obligations of the disclosure assessment commissions and therefore the scope of their responsibility. Finally, the cases that can cause the public loss due to the decisions of the disclosure assessment commissions are discussed.
\end{abstract}

Keywords: the disclosure assessment commissions, the disclosure mechanism, public loss, the financial responsibility of administration

JEL Code: K19, K34, M41.

\section{Introduction}

In order to reducethe costs of tax compliance, Article 370 of Tax Procedure Law No.213was revised in 2016 toestablishthe disclosure mechanism. According to the new system, if the taxpayer's disclosure is accepted by disclosure assessment commission, the former shall not be subject to a tax audit or an assessment via value assessment commission within the confines of the taxpayers' disclosure. On the contrary, ifthe taxpayers' disclosure is not accepted by the disclosure assessment commission, the taxpenalty shall be assessed at $20 \%$ instead of $100 \%$ of the tax base that has or could have been evaded. However, Article 370 of Tax Procedure Law No. 213 does not specify what will happen if disclosure assessment commissions use (willfully or bydefect or negligence) their margin of appreciation against the law and prevent any assessment of tax or cause an assessment of tax penalty at a lower rate.

Based on the authorization given by the Law, the disclosure assessment commissions were established by the General Communiqué no. 482 (Communiqué no. 482). According to Communiqué no. 482 , these commissions are entitled to provide for the preliminary determination of the cases where there are any signs of tax loss, to determine the taxpayers who will be invited to disclose certain information related to suspected tax loss and to evaluate their explanations. In cases wherethe disclosure assessment commission breaches the lawwillfully or by defect or negligence, the loss of the public income due to the tax loss of the Treasury may occurin theory. However, when the regulations regarding the disclosure mechanism are examined carefully, it will be seen that the cases, where public loss may occur, are quite limited.

\footnotetext{
1 Res. Asst., University of Istanbul Faculty of Law Department of Fiscal Law, selin.ovalioglu@istanbul.edu.tr
} 


\section{Identification of Public Loss}

\subsection{The Notion of Public Loss}

According to Article 71 of Public Financial Management Law No. 5018 (Law No. 5018), the definition of public loss is to cause the decrease or prevent the increase in public resource as a result of decisions, acts or actions contrary to the law which are committed willfully or by defect or negligenceby public officials (Şişman, 2017: 93; Akyilmaz, 2015: 44). Even if it is not explicitly included in Law No. 5018, it is necessary to establish a causal link between the action of the public official and the public loss (Hepaksaz \& Şahin Ipek, 2018: 922). The fact that public revenues are not assessed and collected in accordance with the law is one of the cases that are specifically listed in Article 71 of Law No. 5018 ascausing public loss (Law No. 5018, Article 71 / II / e).

\subsection{Financial Accountability of the Board, Committee or Commissions for Accrual and Collection of Public Revenues}

Per Article 38 of Law No. 5018, public officials who are authorized and charged with imposition, accrual, and collection of public revenues are responsible for the public loss. Whilst the accountability status is regulated, the scope of accountability is not (Üstün et al., 2011: 382). It can be said that those who act against this rule of accountability are obliged to indemnify public loss (Turguter, 2015: 306). Article 7/III of the Court of Accounts Law No. 6085 also requires a causal link between decisions, acts, and actions of the public officials and the public loss in order to rule about the indemnification.

However, the determination of causal link in case of public officials acting on boards, committees or commissions is complicated. Article 31 of the Law No. 5018 clearly sets forth the responsibility arising from the public expenditures made by the decision of the board, committees or commissions. However, there is no clear regulation for the financial responsibility of public officials acting on boards, committees or commissions in case of illegal imposition, accrual, and collection of public revenues. If Article 8 of Law No. 5018 is interpreted in tandem with Article 31 of Law No. 5018, the boards, committees or commissions seem to be liable for the amount of public revenue which is not obtained due to the decision of the boards, committees or commissions (Üstün et. al., 2011: 385).

\subsection{Legal Consequences Arising From Determination of Public Loss}

The public loss can be determined as a result of control, inspection, audit, the judicial review of Court of Accountsor other judicial and administrative proceedings (Hepaksaz \& Şahin İpek, 2018: 924-926). As per Article 71 of the Law no. 5018, public loss determined as a result of control, inspection, audit, the judicial review of Court of Accountsor other judicial and administrative proceedings shall be collected from the relevant persons with the interest to be calculated according to the relevant legislation as of the date of public loss.

Court of Accounts can act both as an audit organ on behalf of the Grand National Assembly and as a judicial power (Kaneti, 2011: 28). If Court of Accounts determine the responsibility of the boards, committees, and commissionsby acting as a judicial power (Üstün et al., 2011: 385), public loss should be demanded with the claim of unjust enrichment from third parties (who are not addressed by Court of Accounts during proceedings) before claiming the responsibility of public officials for accountability (Uzun Çam, 2018: 24). 


\section{Invitation to Disclosure Mechanism}

\subsection{Legal Framework and the Nature of Invitation to Disclosure Mechanism}

Invitation to disclosure mechanism was introduced by Article 22 of Law Amending the Law No. 6728 on Amendments to Certain Laws for the Improvement of the Investment Environment. According to the general rationale of the said Law, the purpose of the invitation to disclosure mechanism and other amendments to the law is to increase the predictability of taxation and to reduce compliance costs.

Pursuant to the Article 370/IV of the Tax Procedure Law No. 213, the Ministry of Finance shall determine the details of the invitation to disclosure mechanism. Accordingly, the Ministry of FinancepublishedCommuniqué no. 482 and identified many issues related to the invitation to disclosure mechanism such as requirements of the invitation to disclosure and establishment of disclosure assessment commissions. Doctrinally, this mechanism is considered as an administrative amicable solution (Oktar, 2018: 425) or as the preparation process of the accrual (Öncel et. al., 2018: 105) or as sui generis activity likecollection of information (Başaran, 2017: 83-85; Rençber, 2018: 138).

\subsection{Requirements of Invitation to Disclosure Mechanism}

Article 370 of Tax Procedure Law requires a preliminary determination by the competent authorities about the existence of certain signs indicating tax loss in order to operate the invitation to disclosure mechanism. Although Article 370 of the Tax Procedure Law No. 213 provides no restrictions other than tax evasion (except for the use of counterfeit invoices up to a certain monetary limit), Communiqué no. 482 lists 16 caseswhen the taxpayers can be invited to the disclosure assessment commission and thus, limits the scope of the invitation to disclosure mechanism.

\subsection{Legal Consequences of the Invitation to Disclose}

If it is concluded that the taxpayer, who is invited to disclose information, does not cause the tax loss, the taxpayer will not be subject to any further tax audit and will not be referred to the commission of appreciation (Oktar, 2018: 425). Ifthe taxpayers' disclosure is not accepted by the disclosure assessment commission, the taxpenalty shall be assessed at $20 \%$ instead of $100 \%$ of the tax base that has or could have been evaded.Differently from Article 370 of Law No. 213, Communiqué no. 482 providesthat it is possible for taxpayers who are invited to disclose information to benefit from a $50 \%$ discount while assessing their tax fine if they submit their declaration within 15 days. It can be said thatthis opportunity is set out in the third paragraph of Article 344 of the Law No. 213 (Rençber, 2018: 142). There is also an opposing view claiming that the public loss will be incurred if the taxpayersare invited to disclose even though they do not meet said requirements and thus, benefit from a discounted rate (Başaran, 2017: 32). 


\section{Rights and Obligationsof the Disclosure Assessment Commissions}

The disclosure assessment commissions are regulated by Communiqué no. 482. According to said Communiqué, it was decided to establish an adequate number of disclosure assessment commissions under the Revenue Administration and also Board of Tax Audit. These commissions are obliged to make a preliminary determination regarding tax loss and to evaluate the disclosures of taxpayers who were invited to disclose. As it is understood from Communiqué no. 482, the commissions will not be required to make any efforts to come up with a preliminary determination and they will determine through the information and documents provided to them (Başaran, 2017: 89).

\section{Problems on Determination of the Public Loss Arising from the Decisions of the Disclosure Assessment Commissions}

In a case where imposition, accrual and collection procedures of public revenues are not made in accordance with the lawas a result ofthe decisions of disclosure assessment commissions, in theory, the public loss may arise due to imposition, accrual, and collection of tax penalty at a lower percentage. The first scenario where the public loss may arise is when a taxpayer, who does not meet the requirements of the invitation, is invited to disclose and said taxpayer is fined with a penalty of $50 \%$ of the amount of tax loss instead of $100 \%$. The second scenario is when the disclosure of a taxpayer, who does not meet the requirements, is accepted and said taxpayer is fined with a penalty of $20 \%$ instead of $100 \%$.

In the first scenario, it is doubtful whether there was a situation contrary to the law in terms of Article 344 of Tax Procedure Law No. 213 (Rençber, 2018: 141). Firstly, the rights and obligations of the disclosure assessment commissions are limited to the determination of taxpayers who will be invited to the disclosure and assessment of their explanations. Hence, the taxation shall be carried out by the tax administration. At this stage, it is possible for tax administration to carry out ageneral tax audit except for the issue subject to disclosure mechanism and continue with additional or ex officiotax assessment. It is important to pay attention to this distinction if and when Article 38 of Law No. 5018 is applied.

In addition, it is very difficult to determine the existence of will, defect and negligence because it will require a re-examination of all the information and documents offered by the taxpayer to the disclosure assessment commissions. Such a review of the public lossallegedly caused by the disclosure assessment commission may possibly lead to allegations regarding violation of trade secrets orviolation of tax privacy. Similar concerns were brought up for reconciliation commissions(Şişman, 2017: 194). Finally, it would be difficult to determine the non-compliance of the decisions of the disclosure assessment commission with the law and consequently the public loss. In Turkish, "the law" is a general expression and in this case, itrefers toboth Tax Procedure Law No. 213 and Communiqué no. 482. It is highly improbable to determine the illegality when these two regulations accommodate conflicting provisions. 


\section{Conclusion}

The financial responsibility of the administration is a requirement of the rule of law (Öncel et al., 2018: 42). Therefore, the disclosure assessment commissions, which determine the taxpayers to be invited to present information and examine it,should be subject to high accountability standards in accordance with the principle of the rule of law. In this context, it has been concluded that the vague scope of the disclosure assessment commissions' duties and responsibilities may lead to certain difficulties in determining their financial responsibility.

On a side note, if the Court of Accounts rules on the existence ofthe public loss as a judicial organ due to the decisions of the disclosure assessment commissions, the State may not request the public loss directly from the disclosure assessment commissions. In this case, there is a possibility thatthe public loss may be demanded with the claim of unjust enrichment from the taxpayer responsible for the tax penaltybased onArticle 49 of the Turkish Code of Obligations (Özçelik, 2012: 15). If the taxpayer is expected to pay the tax penalty, which is determined as a public losswithout relying on a final judgment, a tax audit report or an appraisal committee decision, it will be contrary to the principle of legal security, a subprinciple of the rule of law.

In conclusion, this theoretical study regarding disclosure assessment commissions aims to show the need to make fundamental changes to Turkish system of tax penalties in order to terminate the discussions regarding the constitutionality of the invitation to disclosure mechanism as well as the possible debates on the financial responsibility of the disclosure assessment commissions. For the purpose of guiding the revisions, for example, in France the right to legal remedies is granted prior to exofficiotax assessment and it is decided to deduct $10 \%, 40 \%$ or $80 \%$ of the tax loss depending on the nature of the tax loss (Code Général des Impots, Art. L. 1729-17930; Guttman, 2011: 43-49). It can be said that a similarprovision would be more accurate both in terms of the principle of personality and legality of the fines.

In this context, Article 7 of the Regulation on the Procedures and Principles Regarding Tax Audit may be amended to include a process of disclosure if necessary, before initiating a formal tax audit provided that the period of such exchange of information will be limited. Accordingly, the taxpayer may also benefit from other amicable/administrative solutions since no tax audit has been initiated. Moreover, the taxpayers' right to be heard is also recognized during the tax audit, as it was recognized in front of the Report Evaluation Commissions in accordance with the Article 140 of the Tax Procedure Law No. 213 (Kaşıkçı, 2017: 200).

\section{References}

Akyılmaz, B. (2015), "Kamu Zararının Genel Esasları, Kamu Zararında Rücu ve Rücu Sorumluluğu", Kamu Zararı ve Sorumluluk Çalıştayı Kitabı, Ankara, Sayıştay Başkanlığı, pp. 43-63.

Başaran, Y. (2017). “İaha Davet: Saptanabilenler, Sorular ve Sorunlar”, Vergi Dünyası, No. 433, pp. 6-14.

Gutmann, D. (2011), "Sanctions Fiscales et Constitution", Les Nouveaux Cahiers du Conseil Constitutionel, No. 33, pp. 41-53.

Hepaksaz, E. \&Şahin İpek, E. A. (2018). "Kamu Zararının Tespiti ve Tahsili Sürecinde Ortaya Çıkan Sorunlar ve Çözüm Önerileri”, Atatürk Üniversitesi iktisadi ve Idari Bilimler Dergisi, Vol. 32 (4), pp. 921-940. 
Kaneti, S. (2011). "Sayıştay'ın Anayasal Konumu", Makaleler, İstanbul, 12 Levha Yayınları, pp. 285-301.

Kaşıkçı, M. (2017). Vergi Yargılaması Hukukunda Yargılamanın Yenilenmesi, İstanbul, Filiz Yayınevi.

Oktar, A. (2018). Vergi Hukuku, 13. Baskı, İstanbul, Türkmen Kitabevi.

Öncel, M., Kumrulu, A. \& Çağan, N. (2018). Vergi Hukuku, 27. Baskı, Ankara, Turhan Kitabevi.

Özçelik, B. (2012). "5018 Sayılı Kamu Mali Yönetimi ve Kontrol Kanunu'na Göre Kamu Zararından Sorumluluk", Sayıştay'ın 150. yılı: Kamu Zararı Konulu Panel Tebliğ Metinleri, pp. 10-18.

Rençber, A. (2018). "Vergi Hukukunda İzaha Davet Kurumu ve Kurumun Hukuki Değerlendirmesi", Vergi Sorunları Dergisi, No. 352, pp. 136-149.

Şişman, G. (2017). Vergi Alacağı Açısından Kamu Zararı, İstanbul, Seçkin Kitabevi.

Turguter, N. (2015). Kamu Mali Kontrol Yönetimi ve Kontrol Kanunu Açıklaması, Ankara, TODAiE.

Uzun Çam, M. (2018). “Hesap Yargısının Güncel Sorunları”, Sayıştay Dergisi, No. 110, pp. 9-28.

Üstün, Ü. S., Hepaksaz, E., Kılıç, R. \& Kuluçlu, E., (2011). “Kamu Mali Yönetimi ve Sayıştay Hesap Yargısında Mali Sorumluluk", Süleyman Demirel Üniversitesi Iktisadi Idari Bilimler Fakültesi Dergisi, Vol. 16 (2), pp. 379-397. 